\title{
Anaerobic co-digestion of sewage and brewery sludge for biogas production and land application
}

\author{
1*S. Babel; ${ }^{2}$ J. Sae-Tang; ${ }^{2}$ A. Pecharaply \\ ${ }^{1}$ School of Biochemical Engineering and Technology, Sirindhorn International Institute of Technology, Thammasat \\ University, Pathumthani 12121, Thailand \\ ${ }^{2}$ Environmental Engineering and Management, Asian Institute of Technology, Klong Luang, Pathumthani \\ 12120, Thailand \\ Received 3 June 2008; $\quad$ revised 13 September 2008; accepted 24 November 2008; available online 10 December 2008
}

\begin{abstract}
In Thailand, sewage sludge production from the Bangkok metropolitan area can reach up to 63,000 ton/y by 2010. The Beer-Thai Company, Thailand, produces beer and generates lots of sludge as waste. Sewage sludge and brewery sludge can be used to generate energy which could be saved on the fossil fuels conventionally used as a source of energy. The possibility was explored to mix brewery sludge with sewage sludge at different mixing ratios for anaerobic digestion so that the energy can be generated as biogas and at the same time, digested sewage sludge can be used as fertilizer for agricultural applications. A batch anaerobic reactor under mesophilic condition for a digestion period of 40 days was used in the laboratory. The acrylic reactor was cylindrical with a working weight of $12 \mathrm{~kg}$. The diameter was $23.7 \mathrm{~cm}$ and the height was $34.5 \mathrm{~cm}$. Sludge mixtures at different ratios were fed into the reactors and the optimum mixing ratio was determined. Experimental results showed that the sludge mixture at ratio of 25:75 \% by weight (sewage:brewery) yielded higher biogas production. A reduction in heavy metals and pathogens was observed at this ratio after the digestion indicating its safe use as fertilizer. Nitrogen content was about $4.95 \%$ which is well above the commercial fertilizers. At optimum mixing ratio of 25:75, the amount of the generated biogas is $1.15 \times 10^{6} \mathrm{~m}^{3} / \mathrm{y}$. This large amount of biogas is equivalent to 1.44 million $\mathrm{kWh} / \mathrm{y}$ of electricity, 561,000 L/y of diesel oil and $936,000 \mathrm{~L} / \mathrm{y}$ of vehicle gasoline.
\end{abstract}

Key words: Digested sludge, mixing ratio, nutrient recycling, energy, agricultural application

\section{INTRODUCTION}

Bangkok, Thailand, with about 10 million people, generates large amounts of wastewater. During the wastewater treatment, it produces a huge amount of sludge which causes a serious disposal problem.

Utilization of sludge for agricultural application is increasing instead of the traditional disposal option as it recycles nutrients. It is predicted that Bangkok metropolitan administration (BMA) will produce up to 63,000 ton/y of sewage sludge by 2010 (Stoll, 1995; Eckhardt and Khatiwada, 1998). The Beer-Thai (1991) Co.,Ltd, Thailand, which produces beer, generates $100-120 \mathrm{~m}^{3} /$ day of sludge as waste (Pecharaply, 2007).

This is known to be one of the most interesting biosludges as it is rich in plant nutrients especially phosphorus and nitrogen. In addition, it has low heavy metal concentrations and is good for digestion. Sewage sludge and brewery sludge of the wastewater treatment plant (WWTP) represents a source of

ه*Corresponding Author Email: sandhya@siit.tu.ac.th Tel. +6629 869 009, Fax. +6629 869009 energy, biogas and a by-product of anaerobic digestion. Biogas can be considered as an alternative source of energy when facing an energy crisis.

In China, about 25 million people use biogas for cooking and lighting for 8-10 months a year. China also has sound experience in running diesel and gasoline engines with biogas (Marchaim, 1992). This could be saved on the nonrenewable sources of energy such as fossil fuels that tend to deplete rapidly and at the same time, sludge can be used to supply nutrients to soil and for soil amendment. However, if it be improperly managed, potential risk to both environment and public health may occur from the accumulation of heavy metals and organic compounds, as well as pathogen contamination. Co-treatment by anaerobic digestion of different types of wastes such as municipal waste, industrial waste, sewage sludge and other biowaste is a common practice for waste management elsewhere (Westlake, 1995; Voutsa et al., 1996; Tang et al., 1997). The co-treatment digester 
should receive wastes in a combination and digesting ratio that can steadily generate a high volume of biogas with high methane content. Luostarinen et al., (2008) investigated the increased biogas production at WWTP through co-digestion of sewage sludge with grease trap sludge from a meat processing plant and found that $66 \%$ of methane gas could be yielded when sewage sludge and grease trap sludge was used at 95:5 feed on volatile solids basis.

Cecchi et al. (1988) and Hamzawi et al. (1998) found that cumulative biogas production of mixtures increased with increasing proportions of municipal solid waste under mesophilic condition.

Rosenwinkel and meyer (1999) noted that methane concentration in biogas yielded from anaerobic digestion of slaughterhouse residues and municipal wastes was between 66-67\%. Digestion of sewage sludge and macro algae gave 61.4-71.8 \% methane (Cecchi, 1996). It may be a win-win situation for both parties if the brewery sludge is mixed with BMA sludge. This will help in treatment of the brewery sludge instead of disposal on land with no use and BMA would also benefit, since sludge mixtures can be applied to agricultural fields due to low concentrations of heavy metals. The objective of this study is to determine the amount of biogas generated during anaerobic digestion of sewage and brewery sludge at different mixing ratios in laboratory scale experiments. It also investigated the potential use of digested sludge for land application.

\section{MATERIALS AND METHODS}

Raw material and reactor preparation

Sewage sludge was collected from BMA central WWTP, Nong-Khaem, Bangkok and brewery sludge from Beer-Thai Co., Ltd. Lab-scale batch experiments were carried out at the ambient laboratory of Asian institute of technology, Pathumthani, Thailand. This research was carried out in 2003-2004. Energy calculations were done based on the current rates of 2008. The reactor was cylindrical in shape and made up of acrylic. The diameter was $23.7 \mathrm{~cm}$ and height was $34.5 \mathrm{~cm}$. The mixed sludge of $12 \mathrm{~kg}$ was introduced into the reactor manually at the beginning and was closed for the anaerobic digestion process. Two continuous stirrers were operated at $150 \mathrm{rpm}$ and were driven through a guide shaft which ended $25 \mathrm{~cm}$ below the liquid level to avoid gas losses. From the 4.5 L headspace each digester provided, volumetric biogas production was monitored daily by a gas metering unit using water replacement and digital counter which was directly connected to the headspace of the digesters. A U shaped glass tube linked between the digester and gas collector to avoid moisture and minimize analysis error. The reactor was covered by micro fiber in order to maintain the temperature mesophilic condition. A temperature sensor was also installed. The schematic diagram of the anaerobic digester used in this study is shown in Fig. 1.

\section{Determination of sewage sludge and brewery sludge characteristics}

Both types of collected raw sludge were analyzed for various parameters such as $\mathrm{pH}$, moisture content (\% MC), total solids (\% TS), volatile solids (\% VS), total nitrogen (\% TN), total phosphorus (\% TP), total potassium (\% TK), organic carbon (\%), total heavy metal (mg/kg of $\mathrm{Cd}, \mathrm{Cr}, \mathrm{Cu}, \mathrm{Pb}, \mathrm{Ni}, \mathrm{Zn}, \mathrm{Hg}$ ) and pathogens (MPN/100 $\mathrm{g}$ of fecal coliforms). The anaerobically digested sludge from the reactor was also analyzed for the above parameters in order to find its use for land application/agricultural activities. Sewage and brewery sludge were analyzed following the methods as shown in Table 1. Most of the parameters were analyzed following standard methods (APHA, 1995).

\section{Co-digestion of sewage sludge and brewery sludge at various ratios}

The sewage and brewery sludge were mixed at different ratios of 100:0, 75:25, 50:50, 25:75 and 0:100 by weight, respectively. Water was added to the pure brewery sludge in order to maintain TS in the digester to be around 5-10\%, the desired range for anaerobic digestion. Sludge mixtures were analyzed for the following parameters: $\mathrm{pH}, \% \mathrm{MC}, \% \mathrm{TS}, \% \mathrm{VS}$ and \% TCOD before feeding into the digester. The reactor was operated under the ambient temperature, $31-37^{\circ} \mathrm{C}$ which represents mesophilic condition. The retention time was about 40 days and is normally enough for complete digestion. Nitrogen gas was flushed initially to maintain anaerobic conditions and alkali was added to the reactor to maintain neutral $\mathrm{pH}$ which might drop due to VFA generation. The sludge mixture was continuously mixed using stirrers. The amount of biogas, ambient temperature and $\mathrm{pH}$ were monitored everyday. The produced gas was collected in a gas displacement chamber which was directly connected to the headspace of the reactor and measured continuously by the gas metering unit (Fig. 1). Gas chromatography (Shimadzu GC14A) was employed for measuring 
biogas composition using helium as the carrier gas. The detector is thermal conductivity detector (TCD) with the pack column (WG-100 SS Col.1/4 O.D. $\times 1.8 \mathrm{~m}$ ) and the working pressure of $0.75 \mathrm{~kg} / \mathrm{cm}^{2}$. The Injection/ column/detector temperatures were as $50 / 50 / 100{ }^{\circ} \mathrm{C}$, respectively. The optimum mixing ratio was found based on the amount of produced biogas and on the usage of digested sludge for land application.

\section{RESULTS AND DISCUSSION}

Characteristic of sewage sludge and brewery sludge as a baseline

The characteristics of raw sewage sludge and brewery sludge are shown in Table 2. Brewery sludge was slightly alkaline with a very offensive odor. VS were found to be $70.7 \%$ and the sludge was also rich in nutrients such as nitrogen. In sewage sludge, the VS were $39.6 \%$. Some heavy metals in both types of sludge exceeded the standards; for example, Cu in BMA sludge which may be from metal pipes during conveyance or due to discharges from small industries. High concentrations of $\mathrm{Cd}, \mathrm{Pb}$ and $\mathrm{Zn}$ were also observed in brewery sludge and require further investigation to identify the possible sources. BMA sludge had fecal coliforms under the standard Class B (more than 1,000 MPN/g dry weight). Brewery sludge can be classified under the standard Class A(US EPA, 1994) as the fecal coliforms were less than 1,000 MPN/g dry weight.

Characteristics of sewage sludge and brewery sludge at different mixing ratios

Table 3 depicts the characteristics of sludge mixtures at different mixing ratios. The $\mathrm{pH}$ ranged from
7.1-8.4. Moisture content was the highest in pure BMA sludge. VS were found to be high in pure brewery sludge and low in pure BMA sludge. High TCOD values in all sludge indicate high organic content.

Biogas production at different mixing ratios It is evident that from all sludge mixing ratios, pure brewery sludge would yield the maximum biogas production due to high organic content. However, maximum biogas production was not the only criterion to select the optimum mixing ratio. Digested sludge should also be safe to be used for agricultural application.

According to Metcalf and Eddy (1991), total gas production is estimated usually from the percentage of VS reduction. Typical values range from 0.75-1.12 $\mathrm{m}^{3} / \mathrm{kg}$ of destroyed VS. Fig. 2 shows cumulative gas production at different mixing ratios with time. From Fig. 2, it can be seen that the biogas production still showed an upward trend, but the experiment was conducted for 40 days only. When pure BMA sludge was used, only $0.08 \mathrm{~L}$ of biogas was generated. High VFA produced during the digestion may also inhibit the methanogenesis process. It is well known that the presence of heavy metal, oxygen or too high VFA can cause failure of the anaerobic digester (Polprasert, 1996). The greater the brewery sludge content, the higher was the biogas production. Biogas production at the ratio of 25:75 (sewage sludge:brewery sludge) was $126.67 \mathrm{~L}$ and was the highest among three different mixing ratios (75:25, 50:50 and 25:75) used in this study. This was considered to be the optimum mixing ratio based on higher biogas production and the safety of

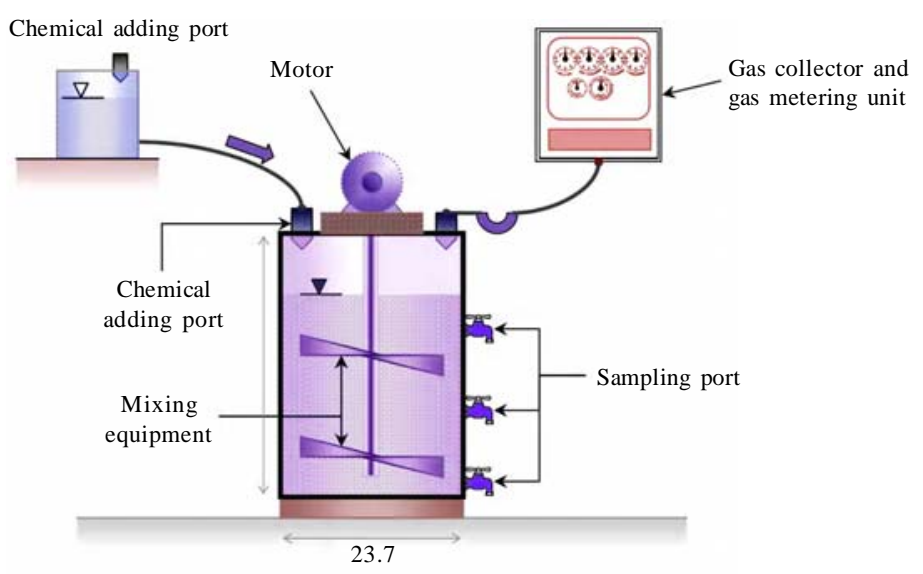

Fig. 1: The schematic diagram of anaerobic digester 
Anaerobic co-digestion of sewage and brewery sludge

Table 1: Parameters and analytical methods of sewage and brewery sludge

\begin{tabular}{|c|c|c|}
\hline Parameters & Units & Analytical methods \\
\hline $\mathrm{pH}$ & - & $\begin{array}{l}\text { Standard methods part } 4500 \text { B: Electrometric method, pH meter } \\
\text { (Glass electrode) }\end{array}$ \\
\hline Moisture content & $\%$ & ASTM D2974-87: Evaporation at $105^{\circ} \mathrm{C}$ \\
\hline Total solids (TS) & $\%$ & Standard method part $2540 \mathrm{~B}$ : TS dried at $105^{\circ} \mathrm{C}$ \\
\hline Total volatile solids (TVS) & $\%$ & Standard method part $2540 \mathrm{E}$ : TS loss after ignited at $550^{\circ} \mathrm{C}$ \\
\hline Total nitrogen & $\%$ & Semi-Micro Kjeldahl method (McGill and Figueiredo, 1993) \\
\hline Total phosphorus & $\mathrm{mg} / \mathrm{kg}$ & $\mathrm{HCLO}_{4}$ acid digestion method (Carter, 1993) ${ }^{\mathrm{a}}$ \\
\hline Total potassium & $\mathrm{mg} / \mathrm{kg}$ & Ammonium acetate method at $\mathrm{pH}=7$ (Hendershot et al., 1993) \\
\hline Organic carbon & $\%$ & Walkley-Black method (Rhoades, 1982) \\
\hline $\begin{array}{l}\text { Total metal concentration: } \\
\mathrm{Cd}, \mathrm{Cr}, \mathrm{Cu}, \mathrm{Pb}, \mathrm{Ni}, \mathrm{Zn}, \mathrm{Hg}\end{array}$ & $\mathrm{mg} / \mathrm{kg}$ & $\begin{array}{l}\text { Mixed acid digestion technique followed by detection using AAS } \\
\text { (Soon and Abboud, 1993) }\end{array}$ \\
\hline Pathogen (Fecal coliforms) & MPN/100 g & MPN technique \\
\hline
\end{tabular}

Table 2: Characteristics of raw sewage sludge and brewery sludge before digestion

\begin{tabular}{llcr}
\hline Parameters & Units & Sewage sludge & Brewery sludge \\
\hline $\mathrm{pH}$ & - & 7.4 & 8.40 \\
Moisture content & $\%$ & 96 & 87.5 \\
Total solids (TS) & $\%$ & 4.0 & 12.5 \\
Volatile solids (VS) & $\%$ & 39.6 & 70.7 \\
5 Total nitrogen & $\%$ & 2.74 & 5.98 \\
Total phosphorus & $\%$ & 3.23 & 5.48 \\
Total potassium & $\%$ & 0.54 & 0.92 \\
Organic carbon & $\%$ & 32.8 & 269 \\
C/N & - & 12.0 & 45 \\
Total COD (TCOD) & $\mathrm{mg} / \mathrm{L}$ & 20,393 & 111,915 \\
Total heavy metal concentration & & & 28 \\
$\mathrm{Cd}$ & & 385 & 16 \\
$\mathrm{Cr}$ & & 4,673 & 75 \\
$\mathrm{Cu}$ & $\mathrm{mg} / \mathrm{kg}$ & 139 & 336 \\
$\mathrm{~Pb}$ & & 156 & 7 \\
$\mathrm{Ni}$ & & 2,387 & 691 \\
$\mathrm{Zn}$ & & 0.19 & 0.3 \\
$\mathrm{Hg}$ & $\mathrm{MPN} / \mathrm{g}$ air- dried sludge & $4 \times 10^{4}$ & $5.6 \times 10^{2}$ \\
Pathogen (Fecal coliforms) & & & \\
& & & \\
\hline
\end{tabular}

digested sludge for agricultural application. Experiments with 100:0 and 0:100 were done to obtain the baseline data. Murto et al. (2004) conducted the experiment on anaerobic co-digestion of sewage sludge and potato processing industrial waste. They found that the highest biogas production rate was $1.2 \mathrm{~L} /$ day at an organic loading rate of $4.2 \mathrm{~kg}$ $\mathrm{VS} / \mathrm{m}^{3} /$ day. Hawkes and Hawkes (1987) reported a gas yield of $0.6 \mathrm{~m}^{3} / \mathrm{kg}$ VS from the digestion of sewage sludge and Gunaseelan (1997) also obsereved a methane yield of $0.42 \mathrm{~m}^{3} / \mathrm{kg}$ VS for potato waste. For co-digestion of manure, slaughterhouse and agricultural waste, gas yields were $1 \mathrm{~m}^{3} / \mathrm{kg}$ VS. The theoretical gas yield for starch is $0.8 \mathrm{~m}^{3} / \mathrm{kg}$. Reported gas yield for pig manure is $0.4 \mathrm{~m}^{3} / \mathrm{kg}$ VS
(Hashimoto,1983) with the methane content in the biogas around $70 \%$.

Composition of biogas was also analysed each day for all ratios (data not shown). Fig. 3 shows the percent of the methane gas produced with time at different mixing ratio. For sewage sludge to brewery sludge ratio at 100:0, 40 days digestion period might not be enough to have complete digestion, thus the methane gas was still increasing slowly. Very small amounts of methane gas could be detected during the first 24 days. During the system imbalance, methane production will decrease (Parkin and Owen, 1986). The total gas production rate may remain unchanged despite falling methane production rates because of increased $\mathrm{CO}_{2}$ production. 
Maximum methane gas concentration was about $65.4 \%$. The presence of oxygen in the biogas composition can be one of the reasons that inhibited the biogas production which might be due to high moisture content in BMA sludge itself. Activity of methanogenic bacteria may have been also inhibited by high heavy metals concentration in BMA sludge. From the study of BMA (1995), it was found that $\mathrm{Cu}$ was above the standard and was considered as a limiting factor. From the results, it can be concluded that the operation of the reactor under high levels of oxygen gas and heavy metals suppressed the activity of methanogenic bacteria. For sewage sludge to brewery sludge ratio at 75:25, production of methane gas is rapid during the first six days and after that it increases slowly. Methane gas could reach up to $71.8 \%$ of total gas composition during the operation period and was $64.9 \%$ on the last day. Compared with the pure sewage sludge, this ratio shows a better result due to the addition of brewery sludge. The co-fermentation experiment with the mixture of sewage sludge, (75\%), and an organic fraction of municipal solid waste (OFMSW), $25 \%$, resulted in a steady increase in methane content in biogas from $15 \%$ in the acidogenic phase to $75 \%$ volume of methane while the carbon dioxide content decreased from $80 \%$ to almost $20 \%$ volume (Sosnowski et al., 2002). OFMSW can be compared with brewery sludge as it has high organic content. The methane content is almost the same. For sewage sludge to brewery sludge ratio at 50:50, methane gas production increased rapidly for the first seven days and after that a slow increase was observed with time. Methane gas could reach up to $71 \%$ of total gas composition during the operation period and was $63 \%$ on the last day. For sewage sludge to brewery sludge ratio at 25:75, a rapid increase in the methane gas was observed during the first seven days and after that it increased slowly. Methane gas could reach up to $72.9 \%$ of the total gas composition during the operation period and was $68.6 \%$ on last day. Biogas composition at 25:75 contains $\mathrm{CH}_{4}, \mathrm{CO}_{2}, \mathrm{~N}_{2}$ and $\mathrm{O}_{2}$ as $68.6 \%, 26.8 \%, 0.7 \%$ and $3.9 \%$, respectively. For sewage sludge to brewery sludge ratio at 0:100, methane gas was produced rapidly during the first seven days. After that a slow increase was observed with time and reached to $72.4 \%$ on the last day. At the ratio of $0: 100$, pure brewery sludge could generate the highest amount of biogas.

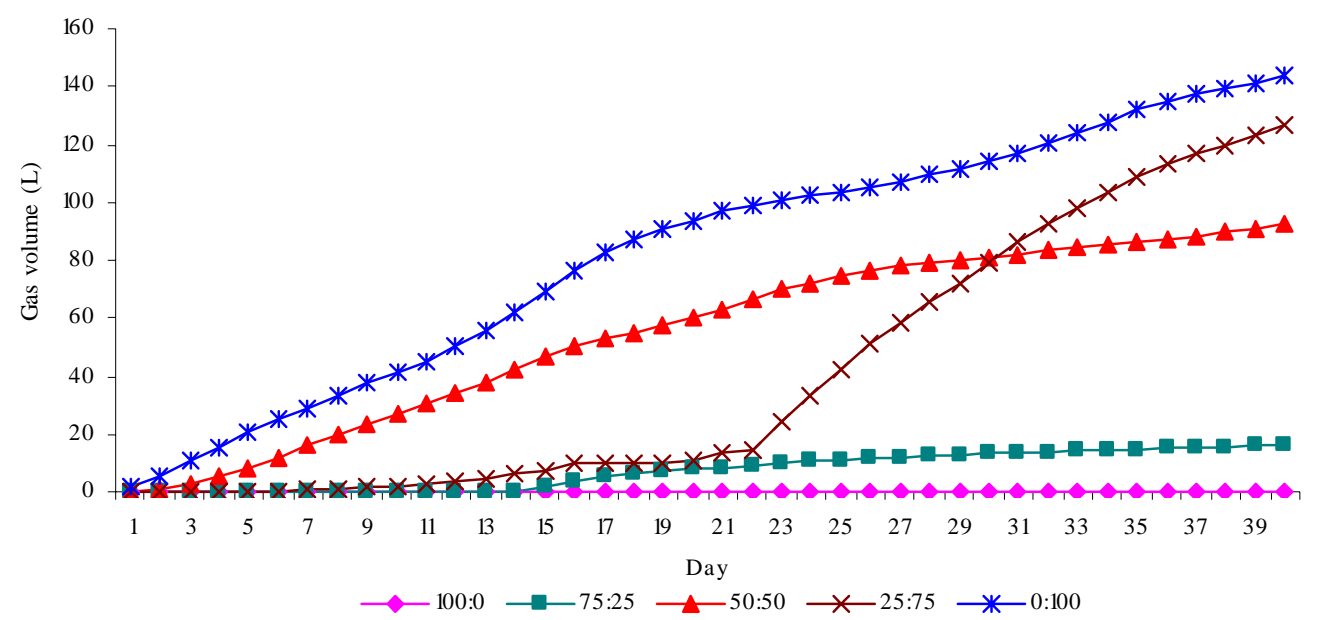

Fig. 2: Cumulative biogas production with time at different mixing ratios (sewage sludge to brewery sludge)

Table 3: Characteristics of sewage sludge and brewery sludge mixtures at different ratios

\begin{tabular}{llrrrrr}
\hline \multirow{2}{*}{ Parameters analysis } & \multirow{2}{*}{ Unit } & \multicolumn{5}{c}{ Sewage sludge to brewery sludge } \\
\cline { 3 - 7 } & & $100: 0$ & $75: 25$ & $50: 50$ & $25: 75$ & $0: 100$ \\
pH & $\%$ & 7.4 & 7.10 & 7.30 & 7.30 & 8.40 \\
MC & 96 & 94.2 & 92.1 & 92.2 & 92.1 \\
TS & 4.0 & 5.80 & 7.90 & 7.80 & 7.90 \\
VS & $\%$ & 52.9 & 61.2 & 63.2 & 68.9 \\
TCOD & $\%$ & 42,000 & 61,280 & 65,619 & 70,800 \\
\hline
\end{tabular}




\section{Energy potential at optimum ratio}

The equivalent amounts of alternative sources of energy as compared to the amount of biogas generated at 25:75 are shown in Table 4 . This shows that a large amount of biogas can be produced by anaerobic digestion. BMA and Beer-Thai produce about 73 and $110 \mathrm{~m}^{3} /$ day of sludge, respectively (density of 1.02 and $1.7 \mathrm{~kg} / \mathrm{L}$ ). At 25:75 ratio, BMA sludge amounting to $27,177,900 \mathrm{~kg}\left(73 \mathrm{~m}^{3} /\right.$ day) and brewery sludge to $54,355,800 \mathrm{~kg}\left(87.6 \mathrm{~m}^{3} /\right.$ day, not all used for $25: 75$ ratio) can generate $1,147,541 \mathrm{~m}^{3} / \mathrm{y}$ of biogas and $777,831 \mathrm{~m}^{3} / \mathrm{y}$ of methane. The calculations are based on the total amount of BMA generated sludge and the amount of biogas produced at the optimum mixing ratio of 25:75. Thus, all BMA sludge can be treated producing a large amount of biogas. Different types of energy that can be generated from the total amount of produced biogas are discussed below and also presented in Table 4 .

- Heat: Biogas can be directly burnt in boilers to produce hot water and steam used for heating and sanitary washing.

- Automobile fuel: After removing carbon dioxide and hydrogen sulfide from biogas to obtain usable methane, the technique of fueling is basically the same as that used for compressed natural gas (CNG) vehicles. It is an environmentally attractive alternative and generates less sound which is a positive aspect, particularly in urban areas. As methane burns very cleanly, exhaust fume emissions are considerably lower than the emission from diesel engines and the emission of nitrogen oxides is very low. If it be used instead of diesel fuel and gasoline, this replacement would save about 19.6 million Baht/y or 604, 606.41 USD/y and 36.1 million Baht/y or USD 1.12 million/y, respectively. - Coal: Biogas production from this study, $1.15 \times 10^{6}$ $\mathrm{m}^{3} / \mathrm{y}$ ) could substitute $918,032 \mathrm{~kg} / \mathrm{y}$ of coal which is equivalent to $4.6 \times 10^{5} \mathrm{Baht} / \mathrm{y}$ or $12,089.36 \mathrm{USD} / \mathrm{y}$.

- Liquefied petroleum gas (LPG): LPG is the most versatile of fuels for heating, hot water, cooking and a host of other uses. The energy replacement from biogas produced in this study to LPG cooking gas is equal to $5.3 \times 10^{5} \mathrm{~kg} / \mathrm{y}$ of LPG and will save about 10.2 million Baht/y or 315,515.11 USD/y.

- Electricity generation: Biogas can be burned to produce steam which has high temperature and pressure. The high pressurized steam can be used to rotate a turbine and generate electricity. The amount of biogas generated each year from BMA sludge and brewery sludge $\left(1.15 \times 10^{6} \mathrm{~m}^{3} / \mathrm{y}\right)$ is equivalent to $1.44 \times 10^{6} \mathrm{kWh}$ and can generate a saving of 5.33 million Baht/y or 140,078.84 USD/y.

Characteristics of digested sludge at different ratios and its suitability for land application

Characteristics of sewage sludge and brewery sludge after digestion at different ratios are shown in Table 5. All digested sludges had a $\mathrm{pH}$ around neutral.

TS were reduced to about 13.3-26.2\%. VS reduction ranged from $14.6 \%$ to $33.6 \%$. The optimum VS reduction should be about $30 \%$ after sludge digestion (Metcalf and Eddy, 1991). The greater the amount of the brewery sludge, the higher is the nitrogen content. All of the

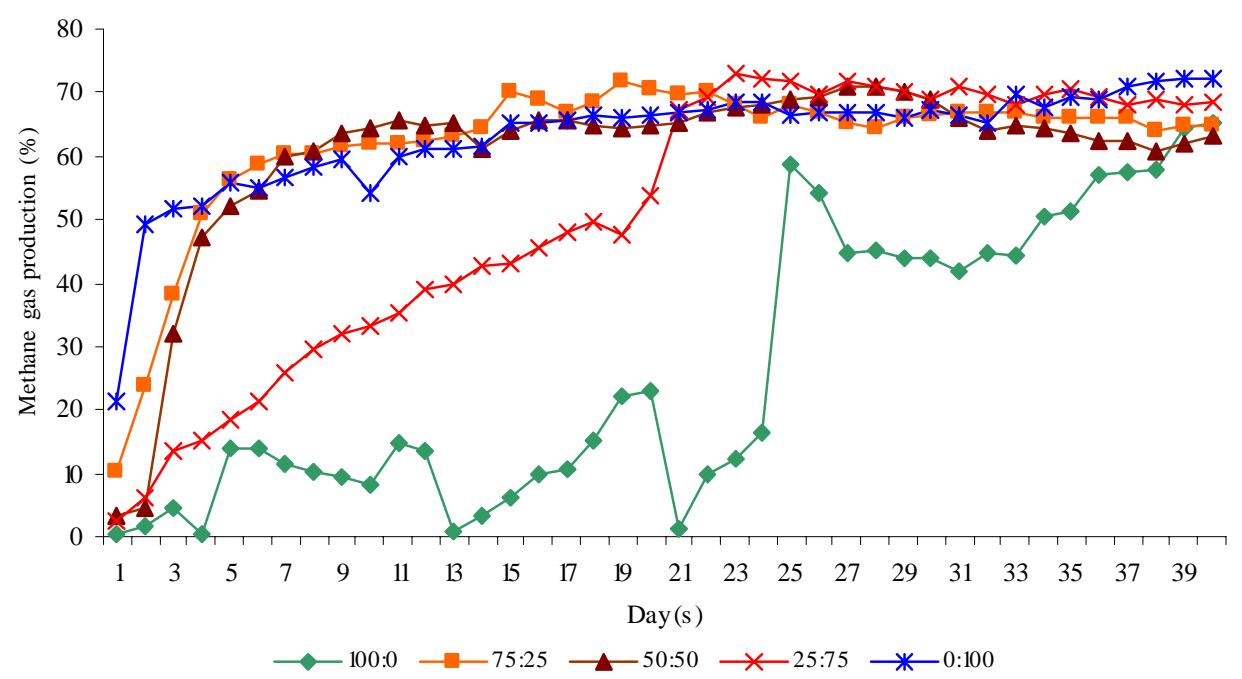

Fig. 3: Percent methane gas production with time at different mixing ratios (sewage sludge to brewery sludge) 
mixed sludge can be applied to soil as a source of plant nutrients. Total nitrogen in digested BMA sewage sludge was lower than the typical anaerobically digested sludge which is about $3 \%$ (Polprasert, 1996). For optimum microbial decomposition, C/N ratio should be 25:1 (Polprasert, 1996). For this study, $\mathrm{C} / \mathrm{N}$ ratio was not adjusted. The sludge mixtures were kept in anaerobic condition for a long period of time (40 days) at about 30$35{ }^{\circ} \mathrm{C}$ and this condition was sufficient to inactivate some of the pathogenic bacteria and helminth eggs. Compared with the baseline study of BMA sewage sludge and brewery sludge, the fecal coliforms were less than 1,000 MPN/g dry weight and were well within the limits of Class A standard (US EPA, 1994) indicating that the digested sludges can be directly used for agricultural application without restrictions. According to AGSS (1995), the survival of fecal coliforms in all digested sludges can be considered under category 2 and is safe for agricultural applications. Digested sludge could meet the compost standards and also proposed BMA standards. Sludge contains high amounts of nitrogen and phosphorus indicating high nutrient value.

Heavy metals concentration in the digested sludge mixtures and comparison with standards

For 100:0, following the German standard and the Australian guidelines, $\mathrm{Cu}$ must be treated so that the sludge can be considered safe for Class B (for agriculture). This sludge can be applied to the land that has low $\mathrm{Zn}$ concentration as the $\mathrm{Zn}$ content is slightly high. The sludges meet the U.S standards for clean sludge except $\mathrm{Cu}$ which was higher than both the clean sludge limits and ceiling concentration limits.

For 75:25, following the Australian standard, the sludge was well below the standard for Class B. According to the German standard, heavy metals concentration were well below the limit for sludge except $\mathrm{Cd}$ and $\mathrm{Cu}$. However, relaxation on $\mathrm{Cd}$ concentration can be provided that the $\mathrm{pH}$ of soil is in the range of 56. According to US Standards, heavy metals concentration were well below the clean sludge limit and ceiling concentration limit except $\mathrm{Cu}$. For 50:50, according to Australian guidelines, it is considered safe for class B. Following German standards, the sludge was considered safe for agricultural application except for $\mathrm{Cd}$ and $\mathrm{Cu}$ concentration. For US standards, the sludges can be used without restriction. For 25:75, which was considered as the optimum mixing ratio, different standards/guidelines are presented in Table 6. It can be seen that according to Australian guidelines, this sludge mixture can not be applied for unrestricted use in class A because of $\mathrm{Cd}, \mathrm{Pb}, \mathrm{Cu}$ and $\mathrm{Zn}$. However, all of the heavy metals concentration in this sludge mixture were well below the standard class B. According to German

Table 4: End use of biogas from BMA sewage sludge to brewery sludge at 25:75 by weight

\begin{tabular}{|c|c|c|}
\hline & Unit & Value \\
\hline Biogas production & $\mathrm{m}^{3} / \mathrm{y}$ & $1.15 \times 10^{6}$ \\
\hline \multirow[t]{2}{*}{ Energy } & $\mathrm{Kcal} / \mathrm{y}^{1}$ & $5.74 \times 10^{9}$ \\
\hline & $\mathrm{MJ} / \mathrm{y}^{1}$ & $2.41 \times 10^{7}$ \\
\hline \multirow[t]{4}{*}{ Diesel fuel } & $\mathrm{Kg} / \mathrm{y}^{1}$ & $4.60 \times 10^{5}$ \\
\hline & $\mathrm{L} / \mathrm{y}^{2}$ & $5.61 \times 10^{5}$ \\
\hline & Baht $/ y^{3}$ & $1.96 \times 10^{7}$ \\
\hline & USD/y & $604,606.41$ \\
\hline \multirow[t]{4}{*}{ Gasoline } & $\mathrm{Kg} / \mathrm{y}^{1}$ & $6.90 \times 10^{5}$ \\
\hline & $\mathrm{L} / \mathrm{y}^{2}$ & $9.36 \times 10^{5}$ \\
\hline & Baht $/ y^{3}$ & $3.61 \times 10^{7}$ \\
\hline & USD/y & $1.12 \times 10^{6}$ \\
\hline \multirow[t]{3}{*}{ Coal } & $\mathrm{Kg} / \mathrm{y}^{1}$ & $9.20 \times 10^{5}$ \\
\hline & Baht $/ y^{4}$ & $4.60 \times 10^{5}$ \\
\hline & USD/y & $12,089.36$ \\
\hline \multirow[t]{3}{*}{ LPG } & $\mathrm{Kg} / \mathrm{y}^{5}$ & $5.30 \times 10^{5}$ \\
\hline & Baht/y ${ }^{6}$ & $1.02 \times 10^{7}$ \\
\hline & USD/y & $315,515.11$ \\
\hline \multirow[t]{3}{*}{ Electricity } & $\mathrm{kWh}^{7}$ & $1.44 \times 10^{6}$ \\
\hline & Baht/y ${ }^{8}$ & $5.33 \times 10^{6}$ \\
\hline & USD/y & $140,078.84$ \\
\hline
\end{tabular}

Note: 1 USD $=32.42$ Baht Biogas has a heat value of 4,500-5,000 kcal $/ \mathrm{m}^{3}$ when its methane content is in range of $60-70 \%$. Assume that all carbondioxide is scrubbed out than $1 \mathrm{~m}^{3}$ of biogas has heat value of 5,000 kcal or $21 \mathrm{MJ}$ and is equivalent to $0.4 \mathrm{~kg}$ of diesel oil, $0.6 \mathrm{~kg}$ of gasoline or $0.8 \mathrm{~kg}$ of coal.

${ }^{2}$ Diesel fuel oil 20 to 60 at $15{ }^{\circ} \mathrm{C}$ density is $820-950 \mathrm{~kg} / \mathrm{m}^{3}$, gasoline (vehicle) at $15.5{ }^{\circ} \mathrm{C}\left(60{ }^{\circ} \mathrm{F}\right)$ density is $737.22 \mathrm{~kg} / \mathrm{m}^{3} ;{ }^{3} 1 \mathrm{~L}$ of diesel fuel is $34.94 \mathrm{Baht}$; $1 \mathrm{~L}$ of gasoline is 38.59 Baht; ${ }^{4} 1$ metric ton of coal costs 500 Baht.; ${ }^{5} 1 \mathrm{~m}^{3}$ of biogas is equivalent to $0.46 \mathrm{~kg}$ of LPG (liquid petroleum gases); ${ }^{6} \mathrm{LPG}$ price is at $19.3 \mathrm{Baht} / \mathrm{kg}$ (290 Baht/15-kg cylinders); ${ }^{7} 1 \mathrm{~m}^{3}$ of biogas is sufficient to provide $1.25 \mathrm{kw} / \mathrm{h}$ of electricity; ${ }^{8}$ Electricity of $1 \mathrm{~kW} / \mathrm{h}$ is equal to 3.7 Baht 
Anaerobic co-digestion of sewage and brewery sludge

Table 5: Characteristics of sewage sludge and brewery sludge at different mixing ratios after digestion

\begin{tabular}{|c|c|c|c|c|c|c|c|}
\hline \multirow[b]{2}{*}{ Parameters } & \multirow{2}{*}{$\begin{array}{l}\text { Proposed } \\
\text { BMA } \\
\text { standards/ } \\
\text { USEPA } \\
\text { standards }^{4} \\
\end{array}$} & \multirow[b]{2}{*}{$\begin{array}{l}\text { Compost } \\
\text { Standards }\end{array}$} & \multicolumn{5}{|c|}{ Sewage sludge to brewery sludge } \\
\hline & & & 100:0 & $75: 25$ & $50: 50$ & $25: 75$ & $0: 100$ \\
\hline $\mathrm{pH}$ & - & $5.5-8.5$ & 7.30 & 7.20 & 7.50 & 7.20 & 7.40 \\
\hline Total solid (\%) & - & $>65$ & 3.50 & 4.20 & 5.80 & 5.80 & 6.00 \\
\hline Volatile solid (\%) & - & - & 38.3 & 43.5 & 55.1 & 57.6 & 61.8 \\
\hline Total nitrogen (\%) & & $0.2-1$ & 2.34 & 3.41 & 4.37 & 4.95 & 5.71 \\
\hline Total phosphorus (\%) & & $0.2-1$ & 2.95 & 3.64 & 4.30 & 4.86 & 5.11 \\
\hline Total potassium (\%) & & - & 0.51 & 0.72 & 0.83 & 0.86 & 0.88 \\
\hline Organic carbon (\%) & & - & 12.77 & 13.17 & 12.43 & 14.76 & 15.25 \\
\hline Organic matter ${ }^{1}(\%)$ & & $15-60$ & 21.96 & 22.65 & 21.38 & 25.38 & 26.23 \\
\hline $\mathrm{C} / \mathrm{N}$ ratio & & - & 5.45 & 3.86 & 2.84 & 2.98 & 2.67 \\
\hline $\begin{array}{l}\text { Fecal coliforms } \\
\text { (MPN/g air-dried sludge) }\end{array}$ & $\begin{array}{l}-/ 1 \times 10^{3}- \\
2 \times 10^{6}\end{array}$ & - & 110 & 2 & 13 & ND & 25 \\
\hline \multicolumn{8}{|l|}{$\begin{array}{l}\text { Heavy metals }{ }^{2} \\
\text { (mg/kg dry wt.) }\end{array}$} \\
\hline $\mathrm{Cr}$ & $1,000 / 1,200$ & - & 333 & 243 & 90 & 69 & 13 \\
\hline $\mathrm{Ni}$ & $400 / 420$ & - & 127 & 81 & 43 & 30 & 7.0 \\
\hline $\mathrm{Pb}$ & $1,000 / 300$ & 565 & 102 & 122 & 274 & 285 & 305 \\
\hline Cd & 20/39 & 19 & 1.6 & 9.40 & 19.8 & 22.1 & 25.3 \\
\hline $\mathrm{Hg}^{3}$ & & - & 0.18 & 0.23 & 0.57 & 0.24 & 0.3 \\
\hline $\mathrm{Cu}$ & $900 / 1,500$ & 725 & 4,425 & 2,123 & 1,415 & 368 & 67 \\
\hline $\mathrm{Zn}$ & $3,000 / 2,800$ & 1,000 & 2,125 & 1,432 & 1,045 & 795 & 630 \\
\hline
\end{tabular}

ND $=$ Not detected

${ }^{1}$ Percent organic matter $=\%$ Organic carbon $\times 1.72$

${ }^{2}$ The accuracy of the heavy metals determination is based on the precision of AAS flame type (HITACHI Z-A230)

${ }^{3}$ Hg was analyzed by the Office of Public Health and Environmental Technology Services, Faculty of Public Health, Mahidol University, Bangkok, Thailand

(AAS flame type VARIANCE 600)

${ }^{4}$ (Dacera, 2007)

Table 6: Comparison of heavy metals with standards in digested sludge at 25:75 (BMA sludge to brewery sludge)

\begin{tabular}{|c|c|c|c|c|c|c|c|c|}
\hline \multirow{2}{*}{$\begin{array}{l}\text { Heavy } \\
\text { metals }\end{array}$} & \multirow{2}{*}{$\begin{array}{l}\text { Value } \\
(\mathrm{mg} / \mathrm{kg})\end{array}$} & \multirow{2}{*}{ BMA standard ${ }^{1}$} & \multicolumn{2}{|c|}{ Australian guidelines $^{2}$} & \multicolumn{2}{|c|}{ German standards ${ }^{3}$} & \multicolumn{2}{|c|}{ US standard ${ }^{4}$} \\
\hline & & & Class A & Class B & $\begin{array}{c}\text { Limit for } \\
\text { sludge }\end{array}$ & Limit for soil & Clean sludge limit & $\begin{array}{c}\text { Ceiling } \\
\text { conc. limit }\end{array}$ \\
\hline $\mathrm{Cd}$ & 22.1 & $x$ & $\bar{x}$ & $\checkmark$ & $x$ & $\bar{x}$ & $\checkmark$ & $\checkmark$ \\
\hline $\mathrm{Pb}$ & 285 & $\checkmark$ & $x$ & $\checkmark$ & $\checkmark$ & $x$ & $\checkmark$ & $\checkmark$ \\
\hline $\mathrm{Hg}$ & 0.24 & $\checkmark$ & $\checkmark$ & $\checkmark$ & $\checkmark$ & $\checkmark$ & $\checkmark$ & $\checkmark$ \\
\hline $\mathrm{Cr}$ & 69 & $\checkmark$ & $\checkmark$ & $\checkmark$ & $\checkmark$ & $\checkmark$ & $\checkmark$ & $\checkmark$ \\
\hline $\mathrm{Cu}$ & 368 & $\checkmark$ & $x$ & $\checkmark$ & $\checkmark$ & $x$ & $\checkmark$ & $\checkmark$ \\
\hline $\mathrm{Ni}$ & 30 & $\checkmark$ & $\checkmark$ & $\checkmark$ & $\checkmark$ & $\checkmark$ & $\checkmark$ & $\checkmark$ \\
\hline $\mathrm{Zn}$ & 795 & $\checkmark$ & $x$ & $\checkmark$ & $\checkmark$ & $x$ & $\checkmark$ & $\checkmark$ \\
\hline
\end{tabular}

$\checkmark=$ within standards; $x=$ beyond standard limits

${ }^{1}$ AIT (1998)

2 Australian guidelines for sewerage system: Bio-solid management, 1995

${ }^{3}$ Eckhardt and Khatiwada (1998)

${ }^{4}$ USEPA (1993) 
standards, all the heavy metals were in permissible limits for sludge except Cd. For US standards, all of the heavy metals concentration were under clean sludge limits, as well as ceiling concentration limits. For 0:100, heavy metals concentration were well below the Australian guidelines. The concentrations of $\mathrm{Cd}, \mathrm{Pb}$ and $\mathrm{Zn}$ were above the guidelines for Class A. However, the sludge was considered safe in Class B. Following German standards, all heavy metals were within the standard allowable limits for sludge except Cd concentration. For US standards, all of the heavy metals concentration of sludge were well below the clean sludge limit, as well as the ceiling concentration limit except $\mathrm{Pb}$ which was a little bit above the clean sludge limit. Compared with BMA guidelines, at 100:0, only $\mathrm{Cd}$ and $\mathrm{Zn}$ are in the range. These are probably due to the difference between the incoming raw wastewater and seasonal variation. However, Hg was not studied by the BMA. All heavy metals were well below the BMA guidelines except $\mathrm{Cu}$. For 75:25, it is considered safe for agricultural application. For 50:50, Cu should be treated. For 25:75 and 0:100, Cd should be treated. The heavy metals after treating under anaerobic condition was predominated in the forms of sulfide bound and organic matter bound fractions (Kanatip, 1995; Pichit, 2000) which resulting in the least soluble forms and is safe for agricultural use with suggestion for close monitoring after sludge application (Parkpian et al., 2002).

\section{CONCLUSION}

Observing the amount of the biogas generated at different ratios, it was found that the maximum quantity of biogas was generated at a mixing ratio of 25:75 (optimum) and was 126.67 L. However, a longer digestion period may be required because the biogas production was still increasing slowly after 40 days at every mixing ratio. At the optimum mixing ratio (25:75), methane gas could reach up to $72.9 \%$. Biogas contains $\mathrm{CH}_{4}, \mathrm{CO}_{2}, \mathrm{~N}_{2}$ and $\mathrm{O}_{2}$ as $68.6 \%, 26.8 \%, 0.7 \%$ and $3.9 \%$, respectively. This ratio was considered to be the best as it can produce the maximum quantity of biogas and the quality of the digested sludge is also good. It was found that at the optimum mixing ratio, total biogas production is 1,147,541 $\mathrm{m}^{3} / \mathrm{y}$. Once it burnt, it will generate about 5,737,707, 650 $\mathrm{kcal} / \mathrm{y}$ of energy or $24,098,361 \mathrm{MJ} / \mathrm{y}$ which is enough to produce $5.61 \times 10^{5} \mathrm{~L} / \mathrm{y}$ of diesel fuel, $9.36 \times 10^{5} \mathrm{~L} / \mathrm{y}$ of gasoline, $9.2 \times 10^{5} \mathrm{~kg}$ of coal, $5.3 \times 10^{5} \mathrm{~kg}$ of LPG and 1.44 $\times 10^{6} \mathrm{kWh} / \mathrm{y}$ of electricity. For heat generation, the biogas can be directly burnt to generate heat. In terms of cost saving, 604,606.41 USD/y of diesel fuel, 1,114,134.48 USD/y of gasoline, 12,089.36 USD/y of coal, $315,515.11 \mathrm{USD} / \mathrm{y}$ of LPG and 140,078.84 USD/y of electricity could be realized. Digested sludge from a mixture of 25:75 is recommended to be used for agricultural application due to its low concentration of heavy metals, high nutrient content (nitrogen content of $4.95 \%$ ) and removal of fecal coliforms. The biogas production was also high at this ratio. With the good sludge quality, BMA can save the cost for fertilizers to be applied in public parks in Bangkok and can also produce biogas which can be used as a source of energy for different purposes.

\section{ACKNOWLEDGEMENTS}

This work was supported partially through Master's scholarship by Asian Institute of Technology (AIT), Pathumthani, Thailand and their financial support is gratefully acknowledged.

\section{REFERENCES}

AIT, (1998). Feasibility study on agricultural use and land application of sewage and nightsoil sludge for Bangkok metropolitan, Asian Institute of Technology, Pathumthani, Thailand.

AGSS, (1995) Bio-solid management report., Australian Guidelines for Sewage System.

APHA, (1995). Standard methods for examinations of water and wastewater, $19^{\text {th }}$ Ed. American Public Health Association, Washington, DC.

ASTM, (1967). International D2974 standard test methods for moisture, ash and organic matter of peat and other organic soils American Society for Testing and Materials.

BMA, (1995). Master plan on treatment and disposal of domestic sewage sludge including nightsoil, oil and grease residues for Bangkok metropolitan, Bangkok, Thailand.

Carter, M. R. (1993). Soil sampling and methods of analysis. Lewis Publishers, USA.

Cecchi, F.; Fraverro, P. G.; Perin, G.; Vallini, G., (1988). Comparison of co-digestion performance of two differently collected organic fractions of municipal solid wastes with sewage sludges., Environ. Tech. Lett. 9 (5), 391-400.

Cecchi, F.; Pavan, P.; Alverez, J. M., (1996). Anaerobic codigestion of sewage sludge: Application to the macroalgae from the venice lagoon., Resour. Conserv. Recy., 17 (1), 57-66.

Dacera, D. D. M., (2007). Extraction and removal of heavy metals from contaminated sludge using raw and fermented liquid from pineapple wastes. Sirindhorn International Institute of Technology, Thammasat University, Dissertation EV-PhD-2007-01.

Eckhardt, H.; Khatiwada, N. W., (1998). Feasibility study of agricultural application of sewage and nightsoil sludges from Bangkok metropolitan, proceedings, water environment federation technical conference and exhibition, 2, Singapore. Gunaseelan, V. N., (1997). Anaerobic digestion of biomass for 
methane production: A review., Biomass Bioenerg., 13 (1), 83-114

Hamzawi, N.; Kennedy, K. J.; Mc Lean, D. D., (1998). Technical feasibility of anaerobic co-digestion of sewage sludge and municipal solid waste., Environ. Tech. 19 (10), 993-1003.

Hashimoto, A. G., (1983). Thermophilic and mesophilic anaerobic fermentation of swine manure., Agr. Wastes, 6 (3), 175-191.

Hawkes, F. R.; Hawkes, D. L., (1987). Anaerobic digestion, in: Bu'lock J.; Kristiansen, B. (Eds.), Basic Biotechnology, Academic Press, London, 337-358.

Hendershot, W. H.; Lalande, H.; Duquette, M., (1993). Soil reaction and exchangeable acidity. In: M. R. Carter (Ed.). Soil sampling and methods of analysis for Canadian society of soil science. Lewis Publishers, Boca Raton, FL. pp. 141145.

Kanatip, R., (1995). Biological heavy metal removal from sewage sludge. Master thesis, AIT.

Luostarinen, S.; Luste, S.; Sillanpaa, M., (2008). Increased biogas production at wastewater treatment plants thorugh co-digestion of sewage sludge with grease trap sludge from a meat processing plant. Bioresource Tech., 100 (1), 79-85.

Marchaim, U., (1992). Biogas processes for sustainable development, Food and Agriculture Organization (FAO). Available at: http://www.fao.org/decrep/t054le/ T0541Eob.htm2004

McGill, W. B.; Figueiredo, C. T., (1993). Total nitrogen, in: Carter, M. (Ed.), Soil sampling and methods of soil analysis, Lewis Publisher, Boca Raton, FL, 201-212.

Metcalf and Eddy Inc., (1991). Wastewater engineering: Treatment, disposal, and reuse, $2^{\text {nd. }}$ (Ed.) New York: McGraw Hill Publication.

Murto, M.; Bjornsson, L.; Mattiasson, B., (2004). Impact of food industrial waste on anaerobic co-digestion of sewage sludge and pig manure., J. Environ. Manage., 70 (2), 101-107.

Parkin, G. F.; Owen, W. F., (1986). Fundamentals of anaerobic digestion of wastewater sludges., J. Environ. Eng., 112 (5), 867-920.
Parkpian, P.; Klankrong, K.; Delaune, R. D.; Jugsujinda, A., (2002). Metal leachability from sewage sludge-amended Thai soils., J. Environ. Sci. Heal. A., 37 (5), 765-791.

Pecharaply, A., (2007). Anaeroboc co-digestion of sewage and brewery sludge. AIT Dissertation EV-07-1.

Pichit, P., (2000). Potential leachability of toxic heavy metals in Bangkok sewage sludge. AIT Master thesis EV-00-13.

Polprasert, C., (1996). Organic waste recycling-technology and management, $2^{\text {nd. }}$ (Ed.) West Sussex: John Wiley and Sons.

Rhoades, J. D., (1982). Soluble salts, in: Page,A. L. Miller, R. H.; Keeney, D. R., (Eds.) Methods of soil analysis: Part 2: Chemical and microbiological properties. Monograph 9, $2^{\text {nd. }}$ (Ed.). ASA, Madison, WI., 167-179.

Rosenwinkel, K. H.; Meyer, H., (1999). Anaerobic treatment of slaughterhouse residues in municipal digesters., Water Sci. Tech., 40 (1), 101-111.

Soon, Y. K.; Abboud S., (1993). Lead, Chromium, Lead and Nickel, in: Carter, M. R. (Ed.), Soil sampling and methods of analysis, Lewis, Boca Raton, FL, 101-108.

Sosnowski, P.; Wieczorek, A.; Ledakowicz, S., (2002). Anaerobic co-digestion of sewage sludge and organic fraction of municipal solid wastes., Adv. Environ. Res. 7 (3), 609-616.

Stoll, U., (1995). Municipal sewage sludge management, environmental systems reviews, Environmental Systems Information Center (ENSIC) No. 39, Bangkok, Thailand.

Tang, S. L.; Wong, C. L.; Ellis, K. V., (1997). An optimization model for the selection of wastewater an sludge treatment alternatives., J. Chart. Inst. Water E., 11 (1), 14-23.

USEPA, (1994). EPA Part 503: Biosolids rule report. EPA/ 832/R-93/003. United States Environmental Protection Agency, Washingtom, DC.

Voutsa, D.; Zachariadis, G.; Samara, C.; Kouimtzis, T., (1996). Evaluation of the toxic content of sludges produced during the biological treatment of municipal and industrial waste waters., J. Environ. Sci. Heal A, 31 (3), 657-671.

Westlake, K., (1995). Waste treatment and disposal, in: Hester, R. E.; Harrison, R. M., (Eds.) The royal society of chemistry, Cambridge: UK, 43-68.

\section{AUTHOR (S) BIOSKETCHES}

Babel, S., School of Biochemical Engineering and Technology, Sirindhorn International Institute of Technology (SIIT), Thammasat University, P.O. Box 22, Pathumthani 12121, Thailand.

Email: sandhya@siit.tu.ac.th

Sae-Tang, J., Environmental Engineering and Management, Asian Institute of Technology, P. O. Box 4, Klong Luang, Pathumthani 12120, Thailand. Email: sjenjira@yahoo.com

Pecharaply, A., Environmental Engineering and Management, Asian Institute of Technology, P. O. Box 4, Klong Luang, Pathumthani 12120, Thailand. Email: athapol.p@cpf.co.th

\section{This article should be referenced as follows:}

Babel, S.; Sae-Tang, J.; Pecharaply, A., (2008). Anaerobic co-digestion of sewage and brewery sludge for biogas production and land application. Int. J. Environ. Sci. Tech., 6 (1), 131-140. 